\title{
THE EVALUATION OF BREEDING VALUE OF SIMMENTAL BULLS FOR MILK PERFORMANCE IN SERBIA
}

\author{
V. Pantelić ${ }^{1}$, M. Plavšić ${ }^{2}$, S. Trivunović ${ }^{2}$, S. Aleksić ${ }^{1}$, Lj. Sretenović ${ }^{1}$, D. \\ Ostojić-Andrić $^{1}$, D. Nikšić ${ }^{1}$ \\ ${ }^{1}$ Institute for Animal Husbandry, Belgrade-Zemun, 11080 Zemun, Republic of Serbia \\ ${ }^{2}$ Faculty of Agriculture, Novi Sad, Republic of Serbia \\ Corresponding author: Vlada Pantelić, e-mail: vladap4@gmail.com \\ Original scientific paper
}

\begin{abstract}
The basis for selection work is knowledge of the quality of bull sires used for conception, as well as how the major traits are passed on to the progeny. BLUP method (Best Linear Unbiased Prediction) is the basis of the most favourable solution for evaluation of additive gene value in cattle production, and it is implemented in various variants depending on the structure of data used. This research included 2.121 Simmental first cavers under control, with lactations completed within one year. All first calvers were located on holdings of individual agricultural producers on the territory of the Republic of Serbia. Evaluation of the bull breeding value for lactation duration, milk production, milk fat yield, yield of $4 \%$ FCM and percentage of milk fat, was carried out by using the mixed model (BLUP), the calculation included random effect of bull sire and fixed effect of the region, year and season of calving. In this study, bull sires which had in two or three regions over 20 daughters - first calvers of Simmental breed. Number of first calving heifers ranged from 22 to 215 animals per bull sire. By using BLUP method in evaluation of breeding value of bulls in terms of yield of milk, milk fat, content of milk fat and 4\% FCMI and by ranking, results were obtained showing superiority and inferiority of breeding males.
\end{abstract}

Key words: Simmental breed, bulls, breeding value, milk performance

\section{Introduction}

Simmental breed of cattle is predominant in Central Serbia, where the total cattle population is approx. 819000 heads, of which approx. 538.000 are cows and pregnant heifers. Active population of Simmental breed in Republic of Serbia consists of animals recorded in the main livestock/cattle registry (approx. 75.000 animals or 14\%). Breeding goal for Simmental breed is to achieve maximum genetic potentials in economically relevant traits, in accordance with economical 
effects of genetic improvement achieved by this breed in developed world countries.

In evaluation of breeding value for milk traits/performance, especially of bulls in progeny testing, in Serbia until recently the CC method - Contemporary comparison was used, as well as selection index, and in last years, the Best Linear Unbiased Prediction is used (BLUP). According to Sullivan and Schaeffer (1994) the Best Linear Unbiased Prediction (BLUP) has become world standard in evaluation of the genetic value.

Vidović et al. (1993) evaluated the breeding value of Simmental bulls based on their progeny using both BLUP and CC method. Results obtained by authors indicated that the evaluation of the bulls' breeding value and their ranks, obtained by BLUP-1 and BLUP-2 methods, were similar to evaluation and rank obtained by CC method.

The effect of selection in population depends, among other things, on the accuracy of the evaluation of additive value of the parent genotype, i.e. breeding value of bull sires, as concluded by Đurđević and Vidović (1994). The authors evaluated the breeding value using BLUP and CC methods. Correlation of the breeding value rank showed that there was no complete concordance between these two methods.

Miščević (1995) obtained in his research results according which the correlation coefficient of the rank showed that there was significantly high dependence between BLUP and CC methods. However, the method of Best Linear Unbiased Parameters, due to inclusion of fixed effects, gave more precise results and more reliable evaluation of the breeding value of male breeding animals.

Stojić (1996) concluded that application of correction factors contributes to the accuracy of the evaluation of the breeding value in the way that more important factors with certain direction of their action are brought to the same level, and also because of increase of repeatability.

Evaluation of the genotype additive value, i.e. accuracy of its evaluation (bull breeding value) is directly associated with selection effect/success in cattle population (Petrović et al. 1997). By using mixed model, random effect of bull sire on milk yield, yield of milk fat, content of milk fat and 4\% FCM and forming of bull rank based on breeding value, results were obtained showing significant superiority or inferiority if male breeding animals.

One of the methods for evaluation of breeding value of cows and bulls is »test-day model«. Advantage of this method is in the correction of the effect of the environment factors on individual cow performance, as stated by Freeman (1998). The »test-day « model is most often used for several traits, primarily milk yield, yield of milk fat, proteins and somatic cell count in milk. »Test-day « model enables genetic evaluation for additional traits, such as persistence, milk yield in specific part of lactation, etc. 
Swalve (1998) pointed out that the »test-day « model, i.e. data collected on the day of testing are used for analysis instead of concluded lactations calculated based on certain daily controls. Conventional system of data collection is an expensive and slow process, and it is necessary to wait for lactations to be put in order before proceeding with the evaluation of genetic value. By application of "test-day" model the attempt is made to calculate the effect of genetic and paragenetic factors immediately and directly when this effect is exhibited, i.e. on the day of testing.

Method officially used by INTERBULL today is multiple trait model using data from many countries, which was developed by Schaeffer and Zhang (1993). This method is based on the hypothesis that the genetic correlation for certain traits between countries is less than one, i.e. that there is interaction between genotype and environment. In this way the milk performance is evaluated, also milk fat and protein yield.

\section{Materials and Methods}

This research included 2.121 Simmental first calvers under control, with lactations completed within one year. All first calvers were located on holdings of individual agricultural producers on the territory of the Republic of Serbia. In selection of model for evaluation of the bull breeding value, it is important to evaluate as accurately as possible, and eliminate the effects of many systematic factors of the environment, and to establish the heritability value for traits included in the selection process. In immediate processing and analysis of data base the following mixed model of least squares was used (Harvey 1990):

\section{Mixed model for evaluation of bull breeding value for milk performance traits (BLUP):}

$$
Y_{i j k l m}=\mu+B_{i}+R_{j}+G_{k}+S_{l}+e_{i j k l m}
$$

$\mathrm{Y}_{\mathrm{ijk} \mathrm{klm}}=$ expression of the trait in $m$ cow, daughter of bull-sire $i$, which produced in $j$ region, and calved in year $k$ and $l$ season

$\mu \quad=$ general average

$\mathrm{B}_{\mathrm{i}} \quad=$ random effect of $i$ bull sire

$\mathrm{R}_{\mathrm{j}} \quad=$ fixed effect of $j$ region

$\mathrm{G}_{\mathrm{k}} \quad=$ fixed effect of $k$ calving year

$\mathrm{S}_{1} \quad$ = fixed effect of $l$ calving season

$\mathrm{e}_{\mathrm{ijk} k \mathrm{~m}}=$ random error 
The evaluation of the breeding value of bulls for following traits: duration of lactation, milk yield, milk fat yield, yield of 4\% FCM and content of milk fat, was calculated using mixed model (BLUP), in which equation also random effect of bull sire and fixed effect of region, year and season of calving were included. Bull sires with over daughters - first calvers of Simmental breed in two or three regions, were tested. Number of first calvers ranged from 22 to 215 per bull sire, and total of 2.121 daughters were tested.

\section{Results and Discussion}

Breeding values and bull rank for milk performance traits in standard lactation, evaluated based on production of their daughters in all regions are presented in Table 1.

Depending on the structure of linear model, which usually contains combination of several effects on traits, absolute BLUP solutions are obtained which are used for ranking of the selection candidates. Equations/formulas contain effects with fixed (region, year, season) and random classification (sires). Model can also include information about relatives, genetic trend in the population, matrix of kinship, genetic groups or their combination. BLUP is the best linear method because it is the least biased method in evaluation of genetic and paragenetic factors, as concluded by Latinović et al. (1997).

The best ranked bull in regard to milk yield was HB 1197 whose production deviated by $357,62 \mathrm{~kg}$, followed by HB 1206 with deviation of 329,60 $\mathrm{kg}$, and on the third place was HB 1334 with deviation of 291,11 kg. The lowest ranked bull was HB 1260 which deviated by $-666,69 \mathrm{~kg}$ and was ranked on 37th place. In front of him was the bull HB 973 with breeding value of $-532,61 \mathrm{~kg}$ ranked 36th. At 35th place in regard to milk yield was the bull HB 1039, with deviation of $-340,92 \mathrm{~kg}$.

Obtained results indicate that the best production was realized by foreign bulls that are on loan in our country or whose semen had been imported for planned insemination of female breeding animals of domestic Simmental population. Some of these bull sires have in their genetic basis certain share of Red Holstein or Montbeliard genes. The lowest ranked bulls were domestic bulls.

In regard to the content of milk fat, the best ranked bull was HB 920 (BV 0,08), followed by HB 921 (BV 0,06), and on the third place the bull HB 1319 (BV 0,06). The lowest ranked bull for the percentage of milk fat was HB 1039 (BV $-0,09$ ), in front of him, ranked 36 was the bull HB 1189 (PV -0,07), and ranked 35th the bull HB 877(PV -0,05). 
Table 1. Superiority (BV) and bull rank for milk performance traits in standard lactation

\begin{tabular}{|c|c|c|c|c|c|c|c|c|c|c|c|}
\hline \multirow{2}{*}{$\begin{array}{r}\text { HB } \\
\text { bull }\end{array}$} & \multirow{2}{*}{$\begin{array}{c}\text { No. of } \\
\text { daughters }\end{array}$} & \multicolumn{2}{|c|}{ DL, days } & \multicolumn{2}{|c|}{ MY, kg } & \multicolumn{2}{|c|}{ CMF, \% } & \multicolumn{2}{|c|}{ MFY, kg } & \multicolumn{2}{|c|}{ 4\%FCM, kg } \\
\hline & & BV & Rank & BV & Rank & BV & Rank & BV & Rank & BV & Rank \\
\hline 671 & 63 & -2.85 & 22 & -181.47 & 32 & 0.03 & 9 & -6.02 & 30 & -162.82 & 32 \\
\hline 788 & 30 & -4.71 & 29 & -209.29 & 33 & 0.02 & 10 & -7.39 & 33 & -194.64 & 33 \\
\hline 877 & 27 & -7.17 & 33 & 152.55 & 8 & -0.05 & 35 & 3.80 & 14 & 118.06 & 13 \\
\hline 895 & 34 & -4.75 & 30 & -6.75 & 20 & 0.00 & 21 & -0.60 & 21 & -11.61 & 20 \\
\hline 920 & 46 & -3.17 & 23 & -81.97 & 27 & 0.08 & 1 & -0.10 & 20 & -34.34 & 23 \\
\hline 921 & 62 & 6.06 & 9 & 123.44 & 12 & 0.06 & 2 & 7.12 & 6 & 156.15 & 7 \\
\hline 926 & 42 & -7.38 & 34 & 97.08 & 15 & -0.04 & 33 & 2.24 & 18 & 72.52 & 17 \\
\hline 973 & 24 & 15.20 & 1 & -532.61 & 36 & 0.05 & 6 & -19.09 & 36 & -499.28 & 36 \\
\hline 975 & 63 & 3.93 & 11 & 55.38 & 18 & 0.00 & 20 & 2.09 & 19 & 53.53 & 18 \\
\hline 978 & 215 & -1.32 & 19 & 76.64 & 17 & 0.01 & 13 & 3.10 & 16 & 77.15 & 16 \\
\hline 980 & 97 & -3.19 & 24 & 165.91 & 5 & -0.02 & 28 & 5.74 & 8 & 152.46 & 8 \\
\hline 1000 & 55 & 5.19 & 10 & 160.88 & 6 & -0.02 & 29 & 5.52 & 9 & 147.09 & 9 \\
\hline 1032 & 46 & 12.37 & 2 & -63.47 & 26 & 0.00 & 19 & -2.39 & 26 & -61.11 & 26 \\
\hline 1039 & 38 & 8.86 & 3 & -340.92 & 35 & -0.09 & 37 & -16.48 & 35 & -383.53 & 35 \\
\hline 1053 & 49 & 7.16 & 6 & 201.98 & 4 & 0.01 & 15 & 8.20 & 5 & 203.80 & 4 \\
\hline 1066 & 67 & 1.07 & 13 & -13.51 & 22 & -0.03 & 31 & -1.73 & 24 & -31.41 & 22 \\
\hline 1102 & 60 & -0.86 & 18 & 7.62 & 19 & 0.06 & 5 & 2.67 & 17 & 43.13 & 19 \\
\hline 1108 & 89 & -3.94 & 25 & -7.04 & 21 & -0.02 & 24 & -0.86 & 22 & -15.75 & 21 \\
\hline 1111 & 27 & -1.34 & 20 & 144.35 & 9 & 0.03 & 8 & 6.89 & 7 & 160.94 & 6 \\
\hline 1121 & 77 & 8.40 & 4 & -101.72 & 29 & 0.01 & 17 & -3.47 & 27 & -92.67 & 28 \\
\hline 1122 & 34 & -4.03 & 26 & 115.94 & 13 & 0.01 & 16 & 4.78 & 11 & 118.10 & 12 \\
\hline 1133 & 36 & -4.22 & 27 & -219.39 & 34 & 0.03 & 7 & -7.40 & 34 & -198.81 & 34 \\
\hline 1143 & 69 & -6.28 & 32 & 88.78 & 16 & 0.00 & 18 & 3.57 & 15 & 89.06 & 15 \\
\hline 1144 & 29 & 6.89 & 7 & -153.65 & 31 & 0.06 & 4 & -3.60 & 28 & -115.54 & 29 \\
\hline 1151 & 60 & -0.08 & 17 & -53.82 & 25 & -0.05 & 34 & -3.86 & 29 & -79.45 & 27 \\
\hline 1166 & 32 & 8.14 & 5 & -30.40 & 23 & -0.02 & 25 & -1.82 & 25 & -39.57 & 25 \\
\hline 1177 & 30 & -2.78 & 21 & 112.68 & 14 & 0.01 & 14 & 4.77 & 12 & 116.62 & 14 \\
\hline 1178 & 77 & 1.00 & 14 & 141.17 & 10 & -0.02 & 26 & 4.71 & 13 & 127.09 & 11 \\
\hline 1185 & 22 & -8.27 & 36 & -137.77 & 30 & -0.04 & 32 & -6.58 & 32 & -153.92 & 31 \\
\hline 1189 & 39 & -7.82 & 35 & -83.53 & 28 & -0.07 & 36 & -6.17 & 31 & -125.95 & 30 \\
\hline 1197 & 38 & 2.28 & 12 & 357.62 & 1 & -0.02 & 27 & 13.16 & 2 & 340.51 & 1 \\
\hline 1198 & 126 & -4.37 & 28 & 137.16 & 11 & -0.01 & 23 & 4.96 & 10 & 129.22 & 10 \\
\hline 1206 & 69 & -5.80 & 31 & 329.60 & 2 & 0.01 & 12 & 13.37 & 1 & 332.33 & 2 \\
\hline 1260 & 54 & -9.67 & 37 & -666.69 & 37 & 0.01 & 11 & -25.78 & 37 & -653.39 & 37 \\
\hline 1287 & 110 & 6.40 & 8 & -30.57 & 24 & -0.01 & 22 & -1.51 & 23 & -34.85 & 24 \\
\hline 1319 & 48 & 0.48 & 16 & 154.68 & 7 & 0.06 & 3 & 8.47 & 4 & 189.03 & 5 \\
\hline 1334 & 37 & 0.59 & 15 & 291.11 & 3 & -0.03 & 30 & 9.69 & 3 & 261.84 & 3 \\
\hline
\end{tabular}


Similar to the previous case, the best ranked bulls were imported ones, however, bulls who are brothers after their father from the famous Horror line, took the first two places. The lowest ranked bull for percentage of milk fat - HB 1039 was ranked exceptionally low also in regard to milk yield - 35th place. Austria has managed by application of strict selection in 2004 to reach the average content of milk fat of $4,21 \%$ for entire population of Simmental cattle in 212.563 concluded lactations (Zoufaly et al. 2005).

Bulls with good results in regard to milk yield also were superior in regard to milk fat yield but with changed mutual order. So the best ranked bull was HB $1206(13,37 \mathrm{~kg})$, followed by the bull HB $1197(13,16 \mathrm{~kg})$, and the bull HB 1344 (9,69 kg).

However, in regard to the lowest ranked bulls for milk fat yield, the situation is identical to results obtained for yield of milk. The lowest ranked bull was HB 1260 with deviation of $-25,78 \mathrm{~kg}$ and at the $37 \mathrm{th}$ place. In front of him at the 36th place is the bull HB 973 with deviation of $-19,09$. At the 35 th place in regard to milk fat yield was the bull HB 1039, with negative breeding value of $16,48 \mathrm{~kg}$.

If milk yield is calculated as $4 \% \mathrm{FCM}$, identical rank of bulls is obtained, however deviation values are slightly higher and lower. The best ranked bull was HB 1197 whose production deviated by $340,51 \mathrm{~kg}$, followed by HB 1206 with breeding value of $332,33 \mathrm{~kg}$, and bull HB 1334 with deviation of $261,84 \mathrm{~kg}$. The lowest production was recorded in daughters of the bull HB 1260 with values deviating by $-653,39 \mathrm{~kg}$ at 37th place. In front of him was the bull HB 973 with deviation of $-499,28$. At 35 th place in regard to yield of $4 \%$ FCM was the bull HB 1039 , with breeding value of $-383,56$.

For duration of lactation, the best ranked bull sire was HB $973(15,20$ days) who had the lowest results for milk performance traits. At the last place, 37th, was the bull HB 1260 (-9,67 days) who was the lowest ranked bull for all tested production traits.

The following authors studied also the evaluation of the bull breeding value using the BLUP method, their ranking, and also their effect on milk performance traits and fertility traits: Latinović et al. (1997), Vidović et al. (1993), Đurđević and Vidović (1994), Sullivan and Schaeffer (1994), Petrović et al. (1997), Miščević (1995), Stojić (1996), Freeman (1998), Swalve (1998), Marković (1999), Panić and Vidović (2006), Trivunović (2006).

Production of milk and milk fat is limited to only one gender, therefore potential capacity of breeding males for these traits is established based on production results of mothers, sisters, daughters. Knowledge of the quality of bulls and how certain traits are transmitted to the progeny is central issue of breeding programs. Application of artificial insemination and long term semen storing 
results in decrease of number of bulls in populations, therefore their individual effect on the selection results is considerably greater.

\section{Conclusion}

Basic requirement of the modern cattle production is improvement and enhancement of the genetic capacities of animals for production of milk, meat and calves. In application of high quality breeding males with proven genetic potential will contribute to improvement of production and reproduction traits of the cattle population in Serbia.

In this process, the evaluation of the parents' breeding value is one of the priorities. Application of linear methods in evaluation of breeding value contributes to significant improvement of the evaluation from the aspect of inclusion of more available information.

BLUP is one of the leading methods used to achieve progress in population genetics, since it is possible to include own results and production results of individual animals. By combining the methodology of mixed model, method of least squares and selection index method, BLUP is applied world wide as standard.

\section{Acknowledgment}

Research was financed by the Ministry of Education and Science Republic of Serbia, projects TR 31053.

\section{Ocena priplodne vrednosti bikova simentalske rase za osobine mlečnosti u Srbiji}

V. Pantelić, M. Plavšić, S. Trivunović, S. Aleksić, Lj. Sretenović, D. Ostojić-Andrić, D. Nikšić

\section{Rezime}

Osnovu za svaki selekcijski rad predstavlja poznavanje kvaliteta bikova očeva koji se koriste za oplodnju, kao i način prenošenja važnijih svojstava na potomstvo. U osnovi najpovoljnijeg rešavanja problema ocene aditivne genotipske vrednosti osobina u govedarstvu leži BLUP metod (Best Linear Unbiased Prediction), koji se primenjuje u raznim varijantama zavisno od strukture podataka.

Ovim istraživanjem je obuhvaćena 2.121 kontrolisana prvotelka simentalske rase, sa laktacijama zaključenim u toku jedne godine. Sve prvotelke su 
se nalazile na imanjima individualnih poljoprivrednih proizvođača na području Republike Srbije. Ocena priplodne vrednosti bikova za osobine trajanje laktacije, proizvodnju mleka, mlečne masti, $4 \%$ MKM i procenat mlečne masti, izračunata je pomoću mešovitog modela (BLUP), u čiju jednačinu je uključen slučajni uticaj bika-oca i fiksni uticaj regiona, godine i sezone telenja. Ispitani su bikovi-očevi koji u dva ili tri regiona imaju 20 i više kćeri prvotelki simentalske rase. Broj prvotelki je bio od 22 do 215 po biku-ocu. Korišćenjem BLUP metoda za ocenu priplodne vrednosti bikova na prinos mleka, mlečne masti, saržaja mlečne masti i 4\% MKM i formiranjem ranga dobijeni su rezultati koji pokazuju znatnu superiornost ili inferiornost priplodnjaka.

\section{References}

ĐURĐEVIĆ R., VIDOVIĆ V. (1994): Ocena oplemenjivačke vrednosti bikova simentalske rase CC i BLUP metodom. Biotehnologija u stočarstvu, 10, 3-4, 39-48. FREEMAN A.E. (1998): Dairy Cattle Breeding. Proceedings of the 6th World Congress on Genetics Applied to Livestock Production. Armidale, Australia. 23, 293. HARVEY W.R. (1990): Mixed model Least Squares and maximum Likelihood Computer Program. User, s Guiede for LSML MW and MIX MDL.

LATINOVIĆ D., GRUBIĆ G., TRIFUNOVIĆ G., LAZAREVIĆ LJ., KOLJAJIĆ V. (1997): Selekcija ishrana i muznost goveda. NIP »Student« Beograd.

MARKOVIĆ M (1999): Mješoviti modeli-BLUP i ANIMAL model u procjeni oplemenjivačke vrednosti bikova holštajn-frizijske rase. Doktorska disertacija. Poljoprivredni fakultet, Novi Sad.

MIŠČEVIĆ B. (1995): Komponente varijansi i genetski trend osobina mlečnosti tokom prve i kasnijih laktacija krava simentalske rase. Doktorska disertacija. Poljoprivredni fakultet, Novi Sad.

PANIĆ J., VIDOVIĆ V. (2006): Optimizacija modela oplemenjivačke vrednosti bikova simentalske rase. Biotechnology in Animal Husbandry, 22, 5-6, 11-20.

PETROVIĆ M.M, LAZAREVIĆ R., LAZAREVIĆ LJ., ALEKSIĆ S., MIŠČEVIĆ B., PERKOVIĆ S. (1997): Proizvodni efekti selekcije aktivne populacije simentalskih goveda u Srbiji. Biotehnologija u stočarstvu, 3-4, 57-64.

SCHAEFFER L.R., ZANG W. (1993): Proc. Open Session INTERBULL Ann.Mtg.Arhus, Denmark, INTERBULL Bulletin No.8.

STOJIĆ P. (1996): Faktori korekcije osobina mlečnosti i njihov doprinos oceni priplodne vrednosti bikova i krava. Doktorska disertacija. Poljoprivredni fakultet, Beograd.

SULLIVAN P.G., SCHAEFFER L.R., (1994): Fixed versus random genetic groups. Proceedings of the 5th World Congress on Genetics Applied to Livestock Production. 18, 482-485, Univ. of Gueleph, Canada. 
SWALVE H.H. (1998): Use of test day records for genetic evalution. Proceedings of the 6th World Congress on Genetics Applied to Livestock Production. 23, 331334. Armidale, NSW, Australia.

TRIVUNOVIĆ S. (2006): Genetski trend prinosa mleka i mlečne masti u progenom testu bikova za veštačko osemenjavanje. Doktorska disertacija. Poljoprivredni fakultet, Novi Sad.

VIDOVIĆ V., VASOVIĆ S., LAZAREVIĆ R. (1993): Ocena oplemenjivačke vrednosti bikova na osnovu potomstva koristeći BLUP i CC metod selekcije. Biotehnologija u stočarstvu, 9, 1-2, 1-6.

ZOUFALY KATARZYNA, STURMLECHNER F., FURST K. (2005): Die österreichische Rinderzucht 2004. Zentrale Arbeitsgemeinschaft österreichischer Rinderzuchter. Wien.

Received 11 February 2011; accepted for publication 19 May 2011 